\title{
Pengaruh persepsi resiko dan kualitas e-commerce terhadap keputusan konsumen membeli fashion online
}

\author{
Lucky Lhaura Van FC ${ }^{1}$, Lisnawita ${ }^{2}$ \\ 1,2Program Studi Teknik Informatika Fakultas Ilmu Komputer Universitas Lancang Kuning \\ Jln. Yos Sudarso Km 8 Pekanbaru, Telp. (+628117532015) \\ e-mail: ${ }^{1}$ lucky@unilak.ac.id, ${ }^{2}$ lisnawita@unilak.ac.id
}

\begin{abstract}
Abstrak
Penelitian ini bertujuan untuk mengetahui pengaruh persepsi konsumen tentang resiko terhadap keputusan pembelian produk fashion toko online, kedua pengaruh media e-Commerce terhadap keputusan pembelian produk fashion.. pengaruh persepsi konsumen tentang resiko dan kualitas pelayanan secara bersama-sama terhadap keputusan pembelian produk fashion toko online, penelitian ini termasuk penelitian kuantitatif. Populasi penelitian adalah mahasiswa/wi dan dosen fakultas Ilmu Komputer yang pernah melakukan pembelian online. Pengumpulan data dilakukan dengan angket, dimana analisis data menggunakan metode non probability sampling yang telah didapat sebanyak 110 sampel penelitian, analisis data menggunakan fitur cronbach's alfa.Hasil dari pPeneltian ini adalah sSemakin rendah resiko yang dipersepsikan oleh konsumen, maka semakin tinggi tingkat keputusan konsumen untuk membeli fashion secara online. Semakin berkualitas pelayanan e-commerce yang disediakan para pengelola situs belanja fashion online, maka semakin tinggi tingkat keputusan konsumen untuk membeli fashion secara online. Rendahnya persepsi resiko dan tingginya kualitas pelayanan elektronik secara bersamaan akan mampu meningkatkan keputusan konsumen untuk membeli fashion secara online.
\end{abstract}

Kata Kunci : Persepsi Resiko, kualitas e-commerce, metode non probability sampling, cronbach's alfa

\begin{abstract}
This research is perceived risk and quality of e-commerce on fashion product online buying decision in faculty of Computer Science. This study includes quantitative research. The population of research is students and faculty lecturer of Computer Science who ever made online purchasing. Data collection is done by questionnaire, where data analysis using non probabity sampling method has been obtained as many as 110 research samples, data analysis using cronbach's alpha feature. Result from Peneltian This is the lower the risk perceived by the consumer, the higher the level of consumer decisions to buy fashion online. high qualified ecommerce services provided by managers of online fashion shopping sites, the higher the level of consumer decisions to buy fashion online. The low perception of risk and the high quality of electronic services will simultaneously increase consumer's decision to buy fashion online.
\end{abstract}

Keywords: perceived risk, quality of e-commerce, non probabity sampling method, cronbach's alfa

\section{Pendahuluan}

Melihat perkembangan fashion online, maka banyak pengembang situs media sosial memberikan ruang bagi para pemasar untuk mengiklankan dan memasarkan produk-produk mereka di situs tersebut. Banyak produk yang bisa dijual secara online diantaranya adalah 
elektronik, aksesoris, otomotif, fashion dan lain sebagainya. Salah satu produk yang cukup disukai masyarakat adalah fashion. Produk kebutuhan harian ini ditawarkan secara online untuk memudahkan calon konsumen memilih-milih produk tanpa harus berada di toko. Konsumen bisa mengunjungi satu situs ke situs lainnya dengan cepat untuk membanding-bandingkan produk fashion yang diinginkan.

Masalah yang terkait dengan persepsi resiko dan juga kualitas pelayanan website menjadi penting untuk dibahas mengingat dampaknya yang cukup berarti dalam menentukan tinggi rendahnya keputusan konsumen untuk membeli produk tertentu secara online. Asumsi ini dilandasi oleh adanya sejumlah teori dan juga kesimpulan empiris yang pernah dilakukan sebelumnya. Schiffman \& Kanuk (2008:170) menyatakan konsumen menghadapi konsekuensi pembelian yang tidak pasti, sehingga konsumen merasakan adanya tingkat resiko tertentu dalam mengambil keputusan pembelian.Masalah yang dirumuskan pada penelitian ini adalah sebagai berikut:

1.Bagaimana pengaruh persepsi resiko terhadap keputusan konsumen membeli produk fashion secara online?

2. Bagaimana pengaruh kualitas pelayanan elektronik e-commerce terhadap keputusan konsumen membeli produk fashion secara online?

3.Bagaimana pengaruh persepsi resiko dan kualitas pelayanan elektronik secara simultan terhadap keputusan konsumen membeli produk fashion secara online?

\section{Tinjauan Pustaka}

Penelitian terdahulu yang pernah dilakukan oleh Napitupulu dan Kartavianu,(2014) dalam A Structural Equations Modeling Of Purchacing Decisions Trough E-Commerce, dimana variabel didalam penelitian ini adalah kualitas informasi dari website, reputasi toko online,kemudahan dalam membayar online,desain situs dan keputusan pembelian menggunakan metode SEM, yang mana hasil dari penelitian ini adalah kualitas informasi dari website,reputasi toko online,kemudahan dalam membayar online,desain situs memiliki pengaruh signifikan terhadap keputusan membeli secara online dan kepercayaan menjadi faktor terpenting dalam keputusan belanja online, sedangkan yang diteliti oleh penelitisekarang variabelnya adalah persepsi resiko, kualitas pelayanan elektronik e-commerce dan keputusan pembelian.

Menurut Penelitian yang dilakukan oleh Moch Suhir,et all., (2014) yang membahas mengenai bagaimana persepsi resiko dan manfaat terhadap keputusan pembelian online.Analisis data menggunakan analisis deskriptif dan analisis regresi berganda. Hasil penelitian menunjukkan bahwa dari ketiga variabel persepsi risiko, persepsi kemudahan dan persepsi manfaat secara bersama-sama berpengaruh terhadap keputusan pembelian online. Dari perhitungan SPSS 13.0 untuk uji $\mathrm{F}$ diketahui bahwa Fhitung $=31,096>$ Ftabel 2,717 dengan signifikansi sebesar $0,000<0,5$. Secara sendiri -sendiri diketahui Persepsi risiko, Persepsi kemudahan Dan Persepsi manfaat berpengaruh signifikan terhadap keputusan pembelian online.

Penelitian dengan topik yang sama juga dilakukan oleh Ratna Maulida Rachmawati (2014) dengan judul Pengaruh Kepercayaan Terhadap Minat Beli Melalui Persepsi Risiko Pada Transaksi Jual Beli Online Melalui Media Sosial menyatakan bahwa hasil penelitian tersebut mendukung efek positif dari kepercayaan pada minat beli dan hasilnya juga mendukung efek negatif kepercayaan pada risiko yang dirasakan dan risiko yang dirasakan terhadap minat pembelian.

\section{Metode penelitian}

Pengumpulan data penelitian berikut pengolahan dan penyajiannya dilakukan Pada Fakultas ilmu Komputer Universitas Lancang Kuning di kota Pekanbaru. Adapun waktu pelaksanaan penelitian dilakukan pada bulan Mei 2017. 
Jenis dan Sumber Data kepada:

Penulis menggunakan sejumlah data untuk keperluan penelitian ini, yang mencakup

a) Data primer, yaitu data yang dihimpun langsung dari sumber pertama, yang dalam hal ini adalah para pengguna internet/online

b) Data sekunder yang diperoleh dari data olahan berupa jurnal, buku dan dokumentasi dari instansi.

Teknik Pengumpulan Data

Data-data penelitian penulis kumpulkan melalui beberapa cara yaitu:

a. Kuesioner, yaitu sebuah daftar tertulis yang berisi sejumlah pernyataan untuk mendapatkan tanggapan responden. Model kuesioner adalah terstruktur dan tertutup dimana yang dibagikan secara langsung berupa fotocopi kuisioner.

b. Dokumentasi, dimana sejumlah data-data pendukung yang penulis butuhkan diperoleh dari jurnal penelitian terdahulu, buku dan bentuk laporan tertulis lainnya.

Populasi dan Sampel

Yang menjadi populasi adalah para konsumen yang sudah pernah membeli produk fashion secara online. Jumlah populasi tidak diketahui pasti sehingga penetapan jumlah sampel dilakukan dengan mengikuti kaidah dari non-probability sampling.

Penetapan sampel dilakukan mengacu kepada teori dari Hair ,yang menetapkan standar penetepan jumlah sampel pada non probability sampling adalah 5 hingga 10 dikali jumlah indikator. Adapun jumlah indikator yang digunakan dalam penelitian ini adalah 22. Penulis mengalikan jumlah indikator $22 \times 5=110$. Sehingga jumlah responden pada penelitian ini adalah sebanyak 110 konsumen yang sudah pernah membeli produk fashion secara online.

Pengujian Instrumen Penelitian

Mengingat teknik pengumpulan data dilakukan dengan memakai kuesioner, maka perlu dilakukan pengujian kevalidan dan konsistensi instrumen penelitian. Pengujian dimaksud dilakukan melalui uji validitas dan reliabilitas menggunakan pengolahan data menggunakan SPSS.20.

\section{Hasil dan Pembahasan}

Terdapat dua jenis variabel dalam penelitian ini yaitu variabel independen yang terdiri dari Persepsi Resiko $\left(\mathrm{X}_{1}\right)$ dan Kualitas Pelayanan Elektronik e-commerce $\left(\mathrm{X}_{2}\right)$ serta variabel dependen yaitu Keputusan Pembelian (Y). Ketiga variabel penelitian tersebut dapat dioperasionalisasikan sebagaimana tabel berikut ini:

\section{Tabel 1. Definisi Operasional Variabel}

\begin{tabular}{|c|c|c|c|}
\hline Definisi Variabel & Dimensi & Indikator & Skala \\
\hline \multirow{2}{*}{$\begin{array}{l}\text { Persepsi Resiko }\left(\mathrm{X}_{1}\right) \text { : } \\
\text { Ketidakpastian yang dihadapi } \\
\text { pada konsumen jika mereka } \\
\text { tidak dapat meramalkan } \\
\text { konsekuensi yang akan terjadi }\end{array}$} & $\begin{array}{l}\text { Resiko } \\
\text { fungsional }\end{array}$ & 1. Cacat produk & \multirow{5}{*}{ Ordinal } \\
\hline & Resiko fisik & $\begin{array}{l}\text { 2. Kesesuaian warna } \\
\text { 3. Kesesuaian desain } \\
\text { 4. Kesesuaian ukuran }\end{array}$ & \\
\hline \multirow{3}{*}{$\begin{array}{l}\text { (Schiffman } \\
\text { 2008:170) }\end{array}$} & $\begin{array}{l}\text { Resiko } \\
\text { keuangan }\end{array}$ & 5. Keamanan pembayaran & \\
\hline & $\begin{array}{l}\text { Resiko } \\
\text { psikologis }\end{array}$ & 6. Kekecewaan & \\
\hline & Resiko waktu & $\begin{array}{l}\text { 7. Membuang waktu mencari } \\
\text { informasi online }\end{array}$ & \\
\hline Kualitas Pelayanan Elektronik & Website design & 1. Desain tampilan situs & Ordinal \\
\hline
\end{tabular}




\begin{tabular}{|c|c|c|c|}
\hline \multirow{4}{*}{$\begin{array}{l}\left(\mathrm{X}_{2}\right): \\
\text { Evaluasi kognitif jangka } \\
\text { panjang pelanggan terhadap } \\
\text { penyerahan produk/jasa oleh } \\
\text { perusahaan melalui perantaraan } \\
\text { situs } \\
\text { (Dikembangkan dari Lovelock } \\
\text { \& Wright, 2007:96) }\end{array}$} & Reliability & $\begin{array}{l}\text { 2. Ketepatan pemenuhan } \\
\text { pesanan } \\
\text { 3. Ketepatan pengiriman } \\
\text { 4. Jaminan kerahasiaan } \\
\text { informasi } \\
\end{array}$ & \\
\hline & Responsiveness & $\begin{array}{l}\text { 5. Kelengkapan informasi } \\
\text { yang dibutuhkan } \\
\text { 6. Kecepatan navigasi pada } \\
\text { situs }\end{array}$ & \\
\hline & Trust & $\begin{array}{l}\text { 7. Menerima dan memahami } \\
\text { kekurangan pada situs } \\
\text { 8. Memiliki harapan-harapan } \\
\text { positif pada situs }\end{array}$ & \\
\hline & Personalization & $\begin{array}{l}\text { 9. Perhatian individual kepada } \\
\text { pelanggan situs } \\
\text { 10. Sarana untuk berkomentar } \\
\text { atau mengajukan pertanyaan }\end{array}$ & \\
\hline $\begin{array}{l}\text { Keputusan Pembelian (Y): } \\
\text { Proses pengintegrasian yang } \\
\text { mengkombinasikan pengethuan } \\
\text { untuk mengevaluasi dua } \\
\text { perilaku alternatif atau lebih } \\
\text { dan memilih salah satu } \\
\text { diantaranya } \\
\text { (Peter \& Olson, dalam } \\
\text { Sangadji \& Sopiah, 2013:332) }\end{array}$ & & $\begin{array}{l}\text { 1. Pilihan produk } \\
\text { 2. Pilihan merek } \\
\text { 3. Pilihan toko } \\
\text { 4. Pilihan waktu } \\
\text { 5. Pilihan jumlah } \\
\text { (Kotler, dalam Simamora, } \\
\text { 2009:20) }\end{array}$ & Ordinal \\
\hline
\end{tabular}

\section{Pengujian Data}

1.Validitas

Kriteria suatu alat ukur dapat disebut valid adalah apabila nilai $r_{\text {hitung }}>r_{\text {tabel. Nilai }} r_{\text {tabel }}$ untuk 30 unit instrumen adalah 0,361.

Tabel.2Hasil Pengujian Validitas

\begin{tabular}{|l|l|l|l|l|l|}
\hline Variabel & Indikator & $\mathrm{r}_{\text {hitung }}$ & $\mathrm{r}_{\text {tabel }}$ & Hasil & Kesimpulan \\
\hline Persepsi Resiko & $\mathrm{X}_{1} .1$ & 0.869 & 0.361 & Valid & Dilanjutkan \\
$\left(\mathrm{X}_{1}\right)$ & $\mathrm{X}_{1} .2$ & 0.873 & 0.361 & Valid & Dilanjutkan \\
& $\mathrm{X}_{1} .3$ & 0.836 & 0.361 & Valid & Dilanjutkan \\
& $\mathrm{X}_{1} .4$ & 0.848 & 0.361 & Valid & Dilanjutkan \\
& $\mathrm{X}_{1} .5$ & 0.905 & 0.361 & Valid & Dilanjutkan \\
& $\mathrm{X}_{1} .6$ & 0.843 & 0.361 & Valid & Dilanjutkan \\
& $\mathrm{X}_{1} .7$ & 0.827 & 0.361 & Valid & Dilanjutkan \\
\hline Kualitas & $\mathrm{X}_{1} .1$ & 0.749 & 0.361 & Valid & Dilanjutkan \\
Pelayanan & $\mathrm{X}_{1} .2$ & 0.852 & 0.361 & Valid & Dilanjutkan \\
Elektronik $\left(\mathrm{X}_{2}\right)$ & $\mathrm{X}_{1} .3$ & 0.855 & 0.361 & Valid & Dilanjutkan \\
& $\mathrm{X}_{1} .4$ & 0.793 & 0.361 & Valid & Dilanjutkan \\
& $\mathrm{X}_{1} .5$ & 0.897 & 0.361 & Valid & Dilanjutkan \\
& $\mathrm{X}_{1} .6$ & 0.932 & 0.361 & Valid & Dilanjutkan \\
& $\mathrm{X}_{1} .7$ & 0.826 & 0.361 & Valid & Dilanjutkan \\
& $\mathrm{X}_{1} .8$ & 0.762 & 0.361 & Valid & Dilanjutkan \\
\hline
\end{tabular}




\begin{tabular}{|l|l|l|l|l|l|}
\hline & $\mathrm{X}_{1.9}$ & 0.939 & 0.361 & Valid & Dilanjutkan \\
& $\mathrm{X}_{1.10}$ & 0.837 & 0.361 & Valid & Dilanjutkan \\
& & & & & \\
\hline
\end{tabular}

Validitas dimaksudkan untuk mengukur apa yang seharusnya diukur (Ferdinand, 2006:236). Dalam hal ini maka metode pengujian yang dilakukan adalah content validity yang menggambaran kesesuaian sebuah pengukur data dengan apa yang akan diukur. Validitas konten juga menunjukkan kecocokan sebuah konten atau isi dari sebuah konsep yang akan diteliti. Instrumen penelitian dikatakan valid apabila $r_{\text {itung }}>r_{\text {tabel }}$ dan sebaliknya tidak valid jika, $\mathrm{r}_{\text {itung }}<\mathrm{r}_{\text {tabel }}$ (Sunyoto, 2009:72).

2. Pengujian Reliabilitas

Reliabilitas sebuah intstrumen penelitian dapat diketahui dengan menggunakan model alpha cronbach's. Koefisien yang reliabilitasnya tergolong baik adalah minimum 0,6. Hasil pengujian reliabilitas menunjukkan informasi sebagai berikut:

Tabel 3.Hasil Pengujian Reliabilitas

\begin{tabular}{|l|l|l|l|l|}
\hline Variabel & $\begin{array}{l}\text { Cronbach's } \\
\text { Alpha }\end{array}$ & $\begin{array}{l}\text { Batasan } \\
\text { Minimum }\end{array}$ & Hasil & Kesimpulan \\
\hline Persepsi Resiko $\left(\mathrm{X}_{1}\right)$ & 0.958 & 0.6 & Reliabel & Dilanjutkan \\
\hline $\begin{array}{l}\text { Kualitas Pelayanan } \\
\text { Elektronik }\left(\mathrm{X}_{2}\right)\end{array}$ & 0.963 & 0.6 & Reliabel & Dilanjutkan \\
\hline Keputusan Pembelian (Y) & 0.935 & 0.6 & Reliabel & Dilanjutkan \\
\hline
\end{tabular}

Hasil pengujian reliabilitas memperlihatkan bahwa seluruh nilai alpha cronbach's pada semua indikator lebih tinggi dari batas minimum 0,6 sebagaimana yang disyaratkan untuk bisa dikatakan reliabel. Dengan demikian maka seluruh indikator bisa digunakan dalam proses pembahasan selanjutnya.

\section{Metode Analisis Data}

\subsection{Analisa Deskriptif}

Analisis ini dimaksudkan untuk melihat kecenderungan tanggapan responden terhadap aspek persepsi resiko, kualitas pelayanan elektronik dan minat beli. Metode yang dipergunakan adalah dengan menganalisis nilai rata-rata (mean) yang akan dilakukan dengan alat bantu SPSS for windows 22, dan kemudian nilai mean tersebut akan dibandingkan dengan tabel acuan penilaian sebagai berikut (Umar, 2009:164):

$$
\begin{aligned}
\mathrm{RS} & =\frac{(\mathrm{m}-1)}{\mathrm{m}} \\
& \frac{(5-1)}{5} \\
\mathrm{RS} & =\quad 0.8 \quad \text { Dimana : } \\
\mathrm{RS} & =\text { Rentang skala } \\
\mathrm{m} & =\text { Jumlah skala (jumlah pilihan jawaban) }
\end{aligned}
$$

Dari nilai Rentang Skala tersebut maka dapat disusun tabel acuan penetapan kriteria seperti diperlihatkan pada tabel 4 berikut ini: 
Tabel .4 Interval Acuan Analisis Deskriptif

\begin{tabular}{|c|l|l|l|}
\hline Rentang Skor & \multicolumn{1}{|c|}{ Persepsi Resiko } & \multicolumn{1}{|c|}{ Kualitas Pelayanan Elektronik } & Keputusan Pembelian \\
\hline $1,00-1,79$ & Sangat beresiko & Sangat buruk & Sangat rendah \\
\hline $1,80-2,59$ & Beresiko & Buruk & Rendah \\
\hline $2,60-3,39$ & Kurang aman & Kurang bagus & Kurang \\
\hline $3,40-4,19$ & Aman & Bagus & Tinggi \\
\hline $4,20-5,00$ & Sangat aman & Sangat bagus & Sangat tinggi \\
\hline
\end{tabular}

Sumber: Data olahan berdasarkan Umar (2009:164)

\subsection{Pengujian Normalitas}

Analisis data dilakukan dengan pengujian model struktural. Model ini dilakukan dengan asumsi penyebaran data yang normal, dan oleh karena itu perlu terlebih dilakukan uji normalitas data. Untuk melakukan pengujian normalitas data, dilakukan dengan uji Kolmogorov-Smirnov (1 sample K-S) melalui SPSS 17 for windows, dengan kriteria sebagai berikut (Suliyanto, 2011:75):

a) Jika nilai asymp. Sig (2-tailed) $<\alpha(0,05)$, maka secara signifikan data tidak berdistribusi normal.

b) Jika nilai asymp. Sig (2-tailed) $>\alpha(0,05)$, maka secara signifikan data berdistribusi normal.

\subsection{Pengujian Regresi Linear Berganda}

Analisis regresi adalah suatu analisis yang mengukur pengaruh variabel bebas (independen) terhadap variabel terikat (dependen). Jika pengukuran melibatkan lebih dari satu variabel bebas maka dinamakan analisis regresi linier berganda. Dikatakan linier karena setiap estimasi nilai diharapkan mengalami peningkatan atau penurunan mengikuti garis lurus. Persamaan regresi linier berganda adalah (Sunyoto, 2009:9):

$\mathrm{Y}=\mathrm{a}=\mathrm{b}_{1} \mathrm{X}_{1}+\mathrm{b}_{2} \mathrm{X}_{2}$, dimana:

$\mathrm{Y} \quad=$ Keputusan pembelian

a $\quad=$ konstanta

$b_{1} X_{1} \quad=$ Koefisien regresi variabel persepsi resiko

$\mathrm{b}_{2} \mathrm{X}_{2} \quad=$ Koefisien regresi variabel kualitas pelayanan elect

3. Pembahasan analisa data

1. Persepsi Resiko

Penilaian tingkat resiko dipersepsikan responden melalui 7 indikator dengan hasil sebagaimana tabel 5 berikut: 
Tabel 5. Rekapitulasi Tanggapan Pada Variabel Persepsi Resiko

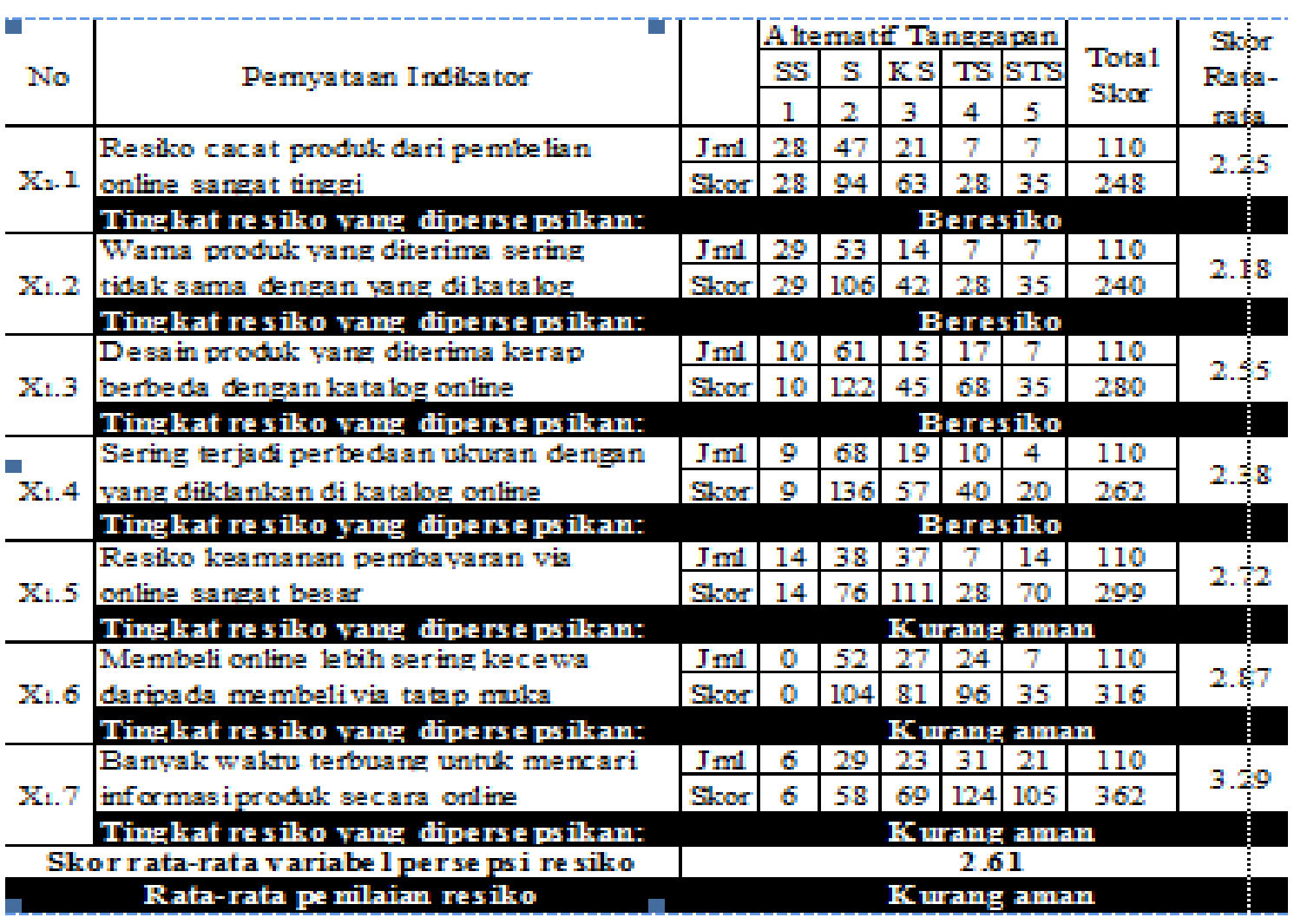

Secara umum rata-rata responden mempersepsikan tingkat resiko berbelanja online pada kategori yang kurang aman bahkan pada beberapa indikasi menunjukkan taraf yang beresiko. Resiko yang terjadi lebih banyak merupakan kesalahan-kesalahan yang terjadi pada fisik produk pesanan yang diterima pemesan, paling sering terjadi adalah pada warna. Secara fisik kebanyakan warna yang diterima oleh pemesan terlihat lebih pudar daripada di foto-foto display pada situs. Hal ini sebenarnya cukup bisa dimaklumi karena pada gambar iklan memang sering mengalami proses editing yang menyebabkan warna terlihat lebih cerah. Namun yang cukup mengecewakan adalah masih sering ditemukan produk yang cacat, misalnya berupa adanya cacat jahitan ataupun sobekan kecil pada bagian-bagian dalam.

Ukuran juga kerap menjadi permasalahan, mengingat banyak merek-merek fashion tidak memiliki ukuran yang standar atau sama dengan merek-merek lain. Akibatnya, pemesan yang bisa menggunakan ukuran tertentu, ketika memesan dengan ukuran biasanya justru mengalami kejadian kelonggaran atau sebaliknya kesempitan dengan ukuran fashion merek tertentu. Karena tidak dicoba lebih dulu, maka pemesanan secara online cukup menjadi masalah tersendiri. Dari sisi desain juga cukup sering terjadi permasalahan. Pada beberapa responden yang tidak menelepon atau melakukan chatting lebih dulu kepada pengelola situs kerap menemukan bahwa ada perbedaan desain pesanan yang diterima.

Justru dari aspek keamanan bertransaksi, responden menempatkan tingkat resikonya dibawah resiko fisik barang, meskipun pada dasarnya rata-rata responden mempersepsikan kurang aman dari sisi pembayaran online seperti itu. Maka wajar jika kemudian rata-rata responden berpendapat bahwa kemungkinan mengalami kekecewaan berbelanja fashion secara online lebih besar resikonya daripada berbelanja dengan metode tatap muka (konvensional). 


\begin{tabular}{|c|c|c|c|c|c|c|c|c|c|}
\hline \multirow{3}{*}{ No } & \multirow{3}{*}{ Pemyataan Indikator } & \multirow{3}{*}{ 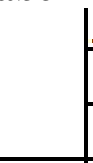 } & \multicolumn{5}{|c|}{ A trematif Tanggapan } & \multirow{3}{*}{$\begin{array}{l}\text { Total } \\
\text { Skar }\end{array}$} & \multirow{3}{*}{$\begin{array}{l}\text { Shór } \\
\mathrm{Ra} a \mathrm{a}- \\
\mathrm{raga}\end{array}$} \\
\hline & & & SS & $\mathrm{S}$ & $\mathrm{KS}$ & TS & STS & & \\
\hline & & & 5 & 4 & 3 & 2 & 1 & & \\
\hline \multirow{3}{*}{ Y1 } & \multirow{2}{*}{$\begin{array}{l}\text { Selalu mengpunakan situs online setiap } \\
\text { kali membeli produk fas hion }\end{array}$} & $\mathrm{Jm}$ & 9 & 16 & 37 & 39 & 9 & 110 & \\
\hline & & Skor & 45 & 64 & 111 & 78 & 9 & 307 & \\
\hline & \multicolumn{9}{|l|}{ Tingkat kepufus an pembe lian: } \\
\hline \multirow{3}{*}{$\mathrm{Y} 2$} & \multirow{2}{*}{$\begin{array}{l}\text { Selalu mengrunakan situs online setiap } \\
\text { memilih merek fashion di pasaran }\end{array}$} & $\mathrm{Jml}$ & 15 & 38 & 36 & 17 & 4 & 110 & \multirow[b]{2}{*}{5} \\
\hline & & Skas & 75 & 152 & 108 & 34 & 4 & 373 & \\
\hline & \multicolumn{9}{|l|}{ Tingkat kepufus an pem be lian: } \\
\hline \multirow{3}{*}{ Y3 } & \multirow{2}{*}{$\begin{array}{l}\text { Selalu berbelania di toko fahion yang } \\
\text { memiliti situs belanja online }\end{array}$} & $\mathrm{Jml}$ & 17 & 8 & 29 & 46 & 10 & 110 & \\
\hline & & Stron & 85 & 32 & 87 & 92 & 10 & 306 & \\
\hline & \multicolumn{9}{|l|}{ Tingkat keputus an pembe lian: } \\
\hline \multirow{3}{*}{ Y4 } & \multirow{2}{*}{$\begin{array}{l}\text { Bisa membeli fashion lapan saja dengan } \\
\text { mengeunakan situs belaria online }\end{array}$} & $\mathrm{Jml}$ & 25 & 32 & 42 & 11 & 0 & 110 & \multirow[b]{2}{*}{3.65} \\
\hline & & Shard & 125 & 128 & 126 & 22 & 0 & 401 & \\
\hline & Tingkat keputus an pem be lian: & \multicolumn{7}{|c|}{ Ting $i$} & \\
\hline \multirow{3}{*}{ Y5 } & \multirow{2}{*}{$\begin{array}{l}\text { Bisa membeli fashion dalam jumlah } \\
\text { yang dinginkan mela hei situs online }\end{array}$} & $\mathrm{Jm}$ & 9 & 10 & 41 & 42 & 8 & 110 & \\
\hline & & $\Delta \sqrt{2}$ & 45 & 40 & 123 & 84 & 8 & 300 & \\
\hline & Tingkat kepufus an pembe lian: & \multirow{2}{*}{\multicolumn{8}{|c|}{$\frac{\text { Kurang }}{3.07}$}} \\
\hline \multirow{2}{*}{\multicolumn{2}{|c|}{ or rat a-rat a variabe 1 ke putus an }} & & & & & & & & \\
\hline & & & & & & & & & \\
\hline
\end{tabular}

Secara umum rata-rata responden mempersepsikan tingkat resiko berbelanja online pada kategori yang kurang aman bahkan pada beberapa indikasi menunjukkan taraf yang beresiko. Resiko yang terjadi lebih banyak merupakan kesalahan-kesalahan yang terjadi pada fisik produk pesanan yang diterima pemesan, paling sering terjadi adalah pada warna. Secara fisik kebanyakan warna yang diterima oleh pemesan terlihat lebih pudar daripada di foto-foto display pada situs. Hal ini sebenarnya cukup bisa dimaklumi karena pada gambar iklan memang sering mengalami proses editing yang menyebabkan warna terlihat lebih cerah. Namun yang cukup mengecewakan adalah masih sering ditemukan produk yang cacat, misalnya berupa adanya cacat jahitan ataupun sobekan kecil pada bagian-bagian dalam.

Ukuran juga kerap menjadi permasalahan, mengingat banyak merek-merek fashion tidak memiliki ukuran yang standar atau sama dengan merek-merek lain. Akibatnya, pemesan yang bisa menggunakan ukuran tertentu, ketika memesan dengan ukuran biasanya justru mengalami kejadian kelonggaran atau sebaliknya kesempitan dengan ukuran fashion merek tertentu. Karena tidak dicoba lebih dulu, maka pemesanan secara online cukup menjadi masalah tersendiri. Dari sisi desain juga cukup sering terjadi permasalahan. Pada beberapa responden yang tidak menelepon atau melakukan chatting lebih dulu kepada pengelola situs kerap menemukan bahwa ada perbedaan desain pesanan yang diterima.

\section{Kualitas Pelayanan Elektronik}

Penilaian responden dalam mengukur kualitas pelayanan elektronik e-commerce pada situssitus belanja online adalah sebagai berikut: 
Tabel 7.Rekapitulasi Tanggapan Pada Kualitas Pelayanan Elektronik

\begin{tabular}{|c|c|c|c|c|c|c|c|c|c|}
\hline \multirow{3}{*}{ No } & \multirow{3}{*}{ Pernyataan Indikator } & & \multicolumn{5}{|c|}{ Alternatif Tanggapan } & \multirow{3}{*}{$\begin{array}{l}\text { Total } \\
\text { Skor }\end{array}$} & \multirow{3}{*}{$\begin{array}{r}\text { Skor } \\
\text { Rata- } \\
\text { rata }\end{array}$} \\
\hline & & & \multirow{2}{*}{\begin{tabular}{|c|}
$\mathrm{SS}$ \\
5 \\
\end{tabular}} & \multirow{2}{*}{\begin{tabular}{|l|}
$S$ \\
4
\end{tabular}} & \multirow{2}{*}{\begin{tabular}{|c|}
$\mathrm{KS}$ \\
3 \\
\end{tabular}} & \multirow{2}{*}{\begin{tabular}{|c|} 
TS \\
2 \\
\end{tabular}} & \multirow{2}{*}{\begin{tabular}{|c|} 
STS \\
1 \\
\end{tabular}} & & \\
\hline & & & & & & & & & \\
\hline \multirow{3}{*}{$X_{2} \cdot 1$} & \multirow{2}{*}{$\begin{array}{l}\text { Situs-situs fashion online pada umumnya } \\
\text { sangat bagus dan menarik }\end{array}$} & Jml & 29 & 27 & 31 & 21 & 2 & 110 & \multirow{2}{*}{3.55} \\
\hline & & Skor & 145 & 108 & \multirow{2}{*}{\multicolumn{3}{|c|}{ Bagus }} & 390 & \\
\hline & kualitas diperse psikan: & \multirow[b]{2}{*}{ Jml } & & & & & & \multirow{3}{*}{$\frac{110}{273}$} & \\
\hline \multirow{3}{*}{$\mathrm{X}_{2} \cdot 2$} & \multirow{2}{*}{$\begin{array}{l}\text { Situs fashion online mampu memenuhi } \\
\text { pesanan secara tept }\end{array}$} & & 3 & 15 & 22 & \multirow{2}{*}{\multicolumn{2}{|c|}{ 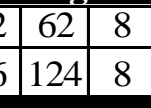 }} & & \multirow{2}{*}{2.48} \\
\hline & & Skor & 15 & 60 & 66 & & & & \\
\hline & kualitas diperse psikan: & \multicolumn{7}{|c|}{ B uruk } & \multirow{3}{*}{2.62} \\
\hline \multirow{3}{*}{$\mathrm{X}_{2} \cdot 3$} & \multirow{2}{*}{$\begin{array}{l}\text { Pengiriman produk dari belanja online } \\
\text { sangat tepat waktu }\end{array}$} & Jml & 1 & 20 & 30 & 54 & 5 & 110 & \\
\hline & & Skor & 5 & 80 & 90 & 108 & 5 & 288 & \\
\hline & \multicolumn{4}{|l|}{ kualitas diperse psikan: } & \multicolumn{4}{|c|}{ Kurang bagus } & \\
\hline & Kerahasiaan data-data pribadi sangat & Jml & 13 & 1 & 39 & 55 & 2 & 110 & \\
\hline $\mathrm{X}_{2} \cdot 4$ & terjaga di situs belanja online & Skor & 65 & 4 & 117 & 110 & 2 & 298 & $\pi$ \\
\hline & kualitas diperse psikan: & & & & Ku & rang & bag & & \\
\hline & Situs online memberikan informasi yang & Jml & 8 & 31 & 48 & 19 & 4 & 110 & \\
\hline $\mathrm{X}_{2} .5$ & dibutuhkan secara lengkap & Skor & 40 & 124 & 144 & 38 & 4 & 350 & 3.18 \\
\hline & kualitas dipe rse psikan: & & & & Ku & ang & bag & & \\
\hline & Navigasi di situs online sangat cepat & Jml & 7 & 7 & 29 & 53 & 14 & 110 & \\
\hline$X_{2} \cdot 6$ & dan mudah & Skor & 35 & 28 & 87 & 106 & 14 & 270 & 2.45 \\
\hline & kualitas diper & & & & & Bur & & & \\
\hline & Saya bisa menerima dan memahami ada & Jml & 12 & 37 & 36 & 19 & 6 & 110 & \\
\hline$X_{2} .7$ & kekurangan pada situs belanja online & Skor & 60 & 148 & 108 & 38 & 6 & 360 & 3.2 \\
\hline & kualitas diperse psikan: & & & & Ku & ang & bag & & \\
\hline & Selalu memiliki harapan positif pada & Jml & 25 & 58 & 26 & 1 & 0 & 110 & 307 \\
\hline $\mathrm{X}_{2} .8$ & perkembangan situs-situs belanjan online & Skor & 125 & 232 & 78 & 2 & 0 & 437 & 3.9 \\
\hline & kualitas diperse psikan: & & & & & Bag & & & \\
\hline & Pengelola situs memberi perhatian individu & Jml & 0 & 17 & 26 & 49 & 18 & 110 & 23 \\
\hline $\mathrm{X}_{2} .9$ & kepada para pelanggannya & Skor & 0 & 68 & 78 & 98 & 18 & 262 & \\
\hline & kualitas diperse psikan: & & & & & Bur & & & \\
\hline & Situs menyediakan ruang dan merespon & Jml & 5 & 21 & 19 & 58 & 7 & 110 & \\
\hline$X_{2} \cdot 10$ & komentar dan pertanyaan pelanggan & Skor & 25 & 84 & 57 & 116 & 7 & 289 & \\
\hline & diperse & & & & & rang & ag & & \\
\hline SKC & ra & & & & & 2. & & & \\
\hline
\end{tabular}

Setiap situs belanja fashion online tentunya memiliki perbedaan dalam hal pelayanannya. Dalam hal ini responden penelitian memiliki penilaian yang kurang bagus terhadap situs-situs yang ada secara umum, bahkan beberapa diantara indikator yang ada justru menunjukkan penilaian responden yang berada pada kategori buruk. Yang paling menjadi kekecewaan responden adalah karena pengelola situs-situs tersebut kurang memberikan perhatian individu/personal yang memuaskan kepada para pemesan. Biasanya setelah transaksi terjadi, para pengelola jarang sekali mengkonfirmasi para pelanggannya untuk menanyakan ketepatan waktu dan pesanan yang diterima oleh konsumen.

Masalah teknis berupa sistem navigasi (fitur petunjuk dan kemudahan berpindah-pindah halaman) yang dimiliki situs belanja online secara umum juga dipersepsikan buruk oleh ratarata responden. Permasalahan utamanya adalah lamanya waktu (loading) perpindahan navigasi. Kejadian ini paling sering terjadi apabila situs-situs belanja tersebut berupa situs-situs blogging dan bukan khusus situs belanja tersendiri. 
Namun meskipun demikian, banyak responden yang masih menaruh harapan tinggi pada perbaikan kualitas pelayanan situs-situs tersebut, mengingat sebagai barang teknologi yang masih relatif baru tentu saja masih banyak kekurangan yang terjadi, khususnya pada infrastruktur jaringan di Indonesia yang belum begitu mapan dibandingkan negara-negara yang sudah maju. Dari sisi desain situs, bahkan rata-rata responden memberikan penilaian yang bagus karena tampilan situs dirasakan sudah sangat bagus dan menarik dari aspek visualnya.

\section{Keputusan Pembelian}

Tingkat keputusan responden dalam membeli produk-produk fashion dengan cara online diukur dengan 8 indikator berikut ini:

Tabel 8.Rekapitulasi Tanggapan Pada Variabel Keputusan Pembelian

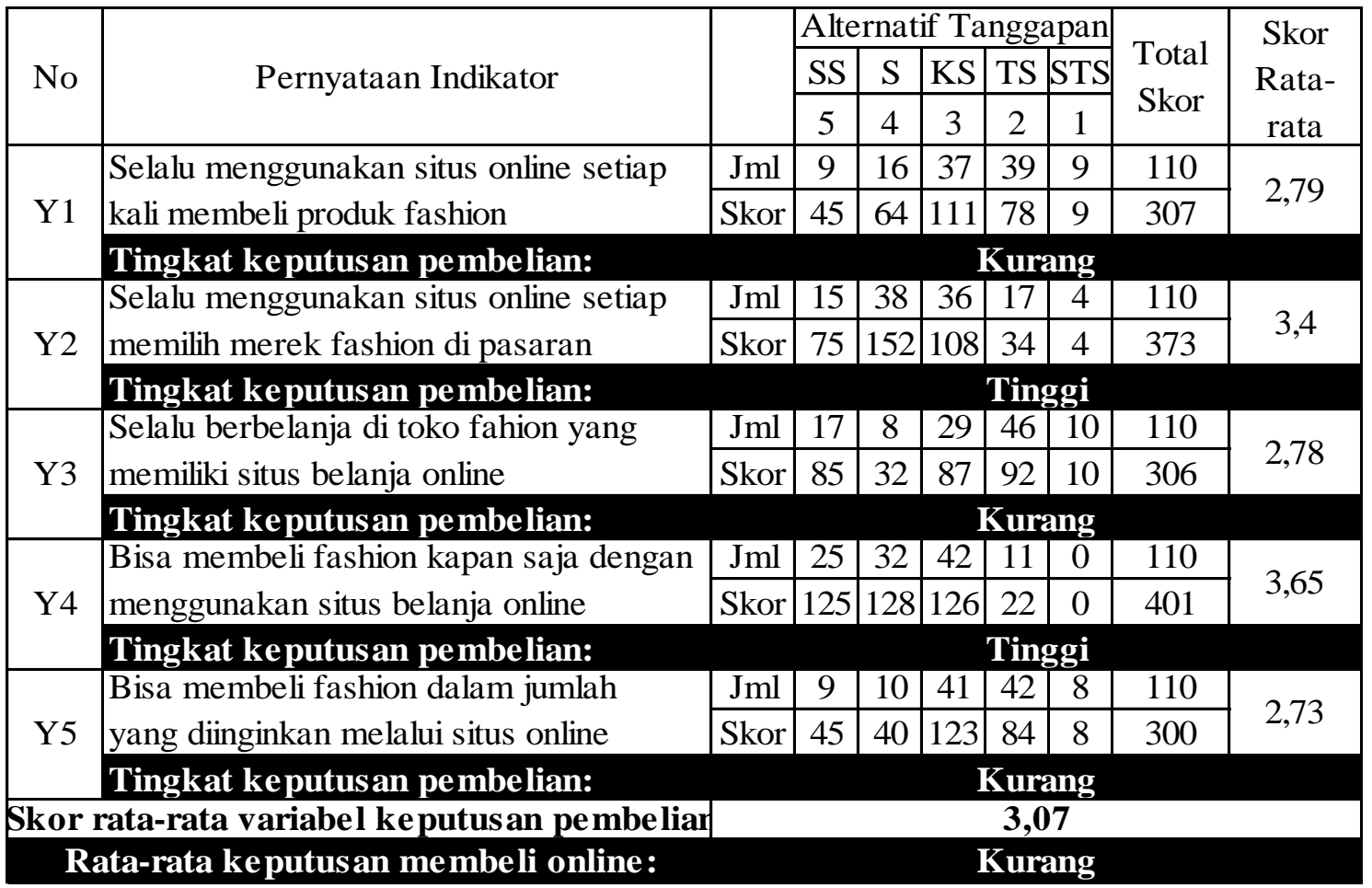

Secara umum keputusan responden untuk membeli produk-produk fashion melalui situs belanja online masih kurang. Pertimbangan kemampuan pengelola situs memenuhi jumlah pesanan dari konsumen adalah yang paling dirasakan menjadi kendala. Banyak dari pengelola situs pada dasarnya bukan merupakan produsen ataupun pemasar, akan tetapi lebih merupakan penyedia saluran distribusi e-commerce dengan menyewakan space online kepada para produsen atau pemasar produk fashion. Inilah yang kerap membuat stok di situs belanja online menjadi sangat terbatas.

Meskipun hasil penelitian memperlihatkan bahwa membeli fashion secara online bisa dilakukan kapan saja atau tidak dibatasi oleh waktu, namun pada kenyataannya lebih banyak responden yang tidak menjadikan situs online sebagai satu-satunya tempat berbelanja fashion. Jadi meskipun toko fashion tertentu tidak memiliki situs belanja online, maka hal itu tidak menjadi halangan bagi responden untuk lebih menyukai berbelanja secara konvensional. Alasannya adalah karena berbelanja konvensional lebih aman dari sisi fisik produk dan keamanan pembayarannya itu sendiri. Responden lebih banyak menyukai penggunaan situssitus fashion online untuk melakukan survey merek-merek atau desain yang sedang tren dipasaran. 


\section{4 .Kesimpulan}

Berdasarkan temuan pembahasan hasil penelitian maka dapat ditarik sejumlah kesimpulan sebagai berikut:

1.Semakin rendah resiko yaitu mulai dari level sangat beresiko sampai sangat aman yang dipersepsikan oleh konsumen, maka semakin tinggi tingkat keputusan konsumen untuk membeli fashion secara online.

2.Semakin bagus pelayanan elektronik yang disediakan para pengelola situs belanja fashion online, maka semakin tinggi tingkat keputusan konsumen untuk membeli fashion secara online. 3.Rendahnya persepsi resiko dan tingginya kualitas pelayanan elektronik secara bersamaan akan mampu meningkatkan keputusan konsumen untuk membeli fashion secara online..

\section{Daftar Pustaka}

[1] Dharmmesta, B. Swastha, dan T. H. Handoko, 2008. Manajemen Pemasaran: Analisis Perilaku Konsumen. Penerbit BPFE UGM, Yogyakarta

[2] Hasley, J.P., dan D.G. Gregg. 2010. An Exploratory Study of Website Information Content. Journal of Theoritical and Applied Electronic Commerce Research, vol. 5, No. 3, pp. 27-38. ISSN: 0718-1876

[3] Hasson, Bruno. 2008. Fashion Branding. Penerbit Gramedia Pustaka Utama, Jakarta

[4] He, Binbin dan C. Bach. 2014. Influence Factors of Online Shopping. International Journal of Innovation and Scientific Research, vol. 2, No. 2, pp. 313-320. ISSN: 23518014

[5] Ikeda, A.A., C.A. Martins dan M.C. Campomar. 2013. Signaling Quality in eCommerce Prior to Purchase: Difference Between Luxury e-Retailers and Mass eRetailers. Brazillian Journal Marketing Opinion and Media Ressearch, vol. V, No. 13, pp. 15-33. ISSN: 1983-9456

[6] Jogiyanto, 2007. Model Kesuksesan Sistem Teknologi Informasi. Penerbit Andi, Yogyakarta

[7] Napitupulu, T.A., dan O. Kartavianus, 2014. A Structural Equations Modeling of Purchasing Decision Through e-Commerce. Journal of Theoritical and applied Information Technology, vol. 60, No. 2, pp. 358-364. ISSN: 1992-8645.

[8] Simamora, Bilson, 2013. Membongkar Kotak Hitam Konsumen. Gramedia Pustaka Utama, Jakarta

[9] Suhir, M., I. Suyadi dan Riyadi. 2014. Pengaruh Persepsi Resiko, Kemudahan dan Manfaat Terhadap Keputusan Pembelian Secara Online 9Survei Pengguna Situs Website www.kaskus.co.id). Jurnal Administrasi Bisnis, vol. 8, No. 1, hal. 1--10

[10] Tjiptono, F., Y. Chandra, dan A. Diana, 2009. Marketing Scales. Penerbit Andi, Yogyakarta 